\title{
Özel Okullarda Yetenek Yönetimi Uygulamaları
}

\section{Talent Management in Private Schools}

\section{Demet ZAFER GÜNEŞ ${ }^{*} \quad$ Sultan Bilge KESKINKILIÇ KARA ${ }^{* *}$}

Öz. Bu araştırmanın amacı, özel okullarda yetenek yönetimi uygulamalarının gerçekleşme düzeyini belirlemektir. Araştırma tarama türünde desenlenmiştir. Araştırmanın çalışma evrenini İstanbul'da bulunan özel ilkokul, ortaokul ve liseler oluşturmaktadır. Araştırmanın örneklemini basit tesadüfi yöntemle belirlenmiş olan 257 öğretmen oluşturmuştur. Veriler araştırmacılar tarafından geliştirilen üç alt boyut ve 25 maddeden oluşan Özel Okullar iç̧in Yetenek Yönetimi Ölçeği aracılığı ile toplanmıştır. Verilerin analizi için standart sapma, ortalama, bağımsız örneklem t-testi ve ANOVA testleri kullanılmıştır. Araştırmada öğretmenlerin yetenek belirleme, yetenek kültürü boyutlarına ve yetenek yönetiminin toplamına ilişkin görüşleri "orta" düzeyde iken, yetenek geliştirme boyutunda ise öğretmenlerin görüşlerinin "yüksek" düzeyde bulunmuştur. Yetenek yönetimi uygulamalarına yönelik öğretmenlerin görüşleri; cinsiyet, yaş ve öğrenim durumu değişkenlerine göre istatistiksel olarak anlamlı bir fark göstermemektedir. Çalıştığı kurum ve kıdem değişkenine göre ise yetenek geliştirme boyutunda istatistiksel olarak anlamlı bir fark bulunmuştur. İlkokullarda görev yapan öğretmenlerin görüşlerinin, ortaokul ve liselerde görev yapan öğretmenlerin görüşlerinden farklılaştığı bulunmuştur. Yetenek geliştirme boyutunda kıdem değişkenine göre bu farkın 1-5 yıl kıdeme sahip olanlarla 6-10 yıl kıdeme sahip olanlar arasında olduğu belirlenmiştir.

Anahtar Kelimeler: Yetenek yönetimi, özel okul, okul yönetimi.

\begin{abstract}
The aim of this study is to determine the level of talent management implementations in private schools. The study is designed in the survey model. Target population of the study private schools in Istanbul. The sample of the study consists of 257 teachers. The sample was chosen through simple random sampling. The data of the study was collected through "Talent Management Scale for Private Schools" that include three sub-dimensions and 25 items. In order to analyze the data standard deviation, mean, independent samples t-test, one-way ANOVA analysis were used. According to the findings obtained from this study, the level of teachers opinions regarding talent determining dimension, talent culture dimension and talent management were determined to be moderate. However, their levels of talent developing dimension were found to be high. In addition, it was identified that the opinions of teachers' regarding the talent management implementations showed statistical no significant difference according to gender, age, seniority and educational level variables. The opinions of teachers' regarding the talent management implementations showed statistical significant differences according to the organization where s/he works variable. Tukey-b tests revealed that opinions of primary school teachers' differ from opinions of elementary school teachers' and high school teachers'. According to seniority variable in talent development dimension, this difference was found to be between those who have 1-5 years of seniority and those who have 6-10 years of seniority.
\end{abstract}

Keywords: Talent management, private school, school management.

\begin{tabular}{|c|}
\hline 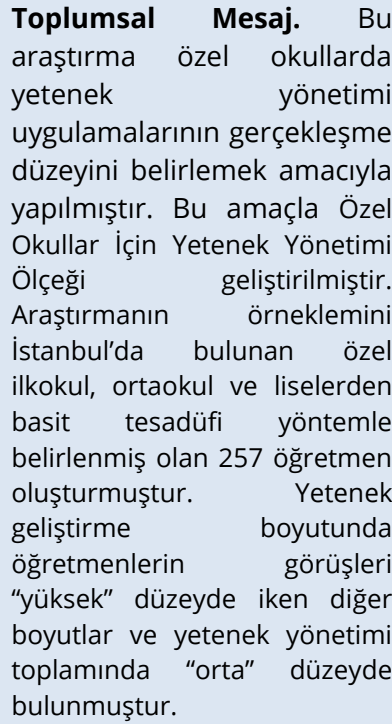 \\
\hline
\end{tabular}

Public Interest Statement. The aim of this study is to determine the level of talent management implementations in private schools. The data of the study was collected through "Talent Management Scale for Private Schools". This scale was developed by researchers for private schools in Turkey. The sample of the study consists of 257 teachers. The level of teachers' opinions regarding talent developing dimension were found to be high. However, other dimensions and talent management were determined to be moderate.

\footnotetext{
*Yrd. Doç. Dr., İstanbul Sabahattin Zaim Üniversitesi, Eğitim Bilimleri Bölümü, demet.gunes@izu.edu.tr

${ }^{* *}$ Yrd. Doç. Dr., İstanbul Sabahattin Zaim Üniversitesi, Eğitim Bilimleri Bölümü, bilge.kara@izu.edu.tr
} 


\section{GíRiş}

Insan kaynakları yönetiminin temeli, çalışanların örgütsel başarıya katkı sağlayan ve etkili şekilde yönetilmesi gereken bir kaynak olarak görülmesidir (Özkara, 1995) ve çalışanlar örgütlerin en değerli ve temel varlıkları olarak değerlendirilmektedirler (Philips ve Edwards, 2009). Modernleşmeyle birlikte gelişen insan kaynakları yönetimi anlayışı çalışanı beceri ve yeteneklerini kullanarak problem çözen, kaliteyi ve verimliliği arttıran emeklerinin yanında duygu ve düşünceleriyle örgüte değer katan varlıklar olarak görmeye başlamıştır (Ertürk, 2011). Yetenek yönetimi kavramı ile birlikte de çalışanların bir bütün olarak insani yönleri de ön plana çıkmıştır (Blass, 2009). Innsan kaynakları yönetimi, örgütlerin amaçlarını gerçekleştirmesi yönünde çalışacak bireylerin örgüte çekilmesi, işe alınması, çalışanların iş memnuniyetlerinin artırılması, her birinin yeteneklerinin belirlenip geliştirilmesidir. Etkili bir insan kaynakları yönetimi süreci için yetenek yönetimi uygulamalarının örgütlerde işe koşulması gerektiğini belirten araştırmacı ve uygulayıcılar vardır. General Elektrik'in ünlü CEO'su Jack Welch Çı̆̆ır Açıcı Liderlik adlı kitapta “Eğer kendinizden daha az yetenekli insanlarla kuşatılmış durumdaysanız bu hiçbir işe yaramaz. Kendiniz çok iyi olsanız bile eğer takım arkadaşlarınız sizden daha iyi ve hızılırsa şansısınız demektir. İ̧̧ yaşamında da bu gereklidir. Asla tek başınıza kazanamazsınız" demektedir. Bu söz örgütsel başarıda yöneticilerin yeteneklerden yararlanarak başarıya ulaşabileceklerini ifade etmektedir.

Yetenek yönetimi kavramı 1997 yılında MCKinsey danışmalık şirketinin ABD'de 77 büyük şirkette yaptıkları araştırmalardan sonra gündeme gelmiş bir kavramdır. Bu araştırmanın sonucunda başarılı şirketlerin etkili bir yetenek yönetimi uygulamalarına sahip olduğu belirlenmiş ve araştırmacılar iyi bir yetenek için kavgaya değer yorumunu yaparak "yetenek savaşları" kavramını kullanmışlardır. Örgütlerde yetenek yönetiminin önemini ortaya koyan bir başka araştırma da Hay Grup (2002) tarafından 50 ülkede 330 şirket üzerinde yapılmış ve bu araştırmanın sonucuna göre çalışanların işten ayrılmalarına neden olan iki önemli etmen belirlenmiştir. Bunlardan birincisi yöneticilerin çalışanların yeteneklerini geliş̧irmelerine ve kullanmalarına olanak vermemeleridir (Hay, 2002). Yani çalışanlar örgüt içinde para veya başka ödüllerle güdülenmekten ziyade yeteneklerini kullanarak örgüt içinde üretken bireyler olmak istemektedirler. Yöneticilerin bunu sağlayabilmelerinin yolu ise etkili bir yetenek yönetimi sürecinden geçmektedir.

Yetenek yönetimi, yüksek nitelikli kişileri örgüte çekme, elde tutma ve geliştirme sürecidir (Davies ve Davies, 2014; Atlı, 2012). Yetenekleri en iyi şekilde yöneten örgütler çalışanlar ile ilgili planlama ve geliştirmeyi etkili yapabilen, kurumlardır. İşgörenlerin gelişim gereksinimlerini gözlemlemek, belirlemek, onların yeteneklerini geliştirmede yardımcı olmak, profesyonel ve kişisel gelişim olanakları sağlamak yöneticilerin önemli bir çalışma alanıdır (Gülfidan, 2008). Çalışanların sahip oldukları yeteneklerin bu derece önemli olmasının nedeni örgütlerin gelecekte yapabileceklerinin ve başarılarının kaynağı olmasıdır (Axelrod, Handfield-Jones ve Welsh, 2001).

Yetenek yönetiminin insan kaynakları yönetiminden farkı insan kaynakları yönetiminde her pozisyondaki çalışanlar ile ilgilenilirken yetenek yönetiminde sadece örgüte özgün bir değer katacak, önemli pozisyonlarındaki çalışanlar ile ilgilenilmesidir. Örgütte çalışanların tamamı değerlidir ancak, birkaç çalışan vardır ki, aslında yükün büyük bir bölümü onların üzerindedir ve kilit noktalarda onlar bulunurlar. Bu çalışanlar vazgeçilmezdir ve kaybedilmeleri işlerin yolundan çıkması anlamına gelebilir (Aytaç, 2014; Tabancalı ve Korumaz, 2014; Lewis ve Heckman, 2006). Ancak örgütlerde sadece yeteneklere odaklanmak iş gücünün büyük çoğunluğunun göz ardı edilmesine neden olabilir (Born ve Heers, 2009) çünkü örgütler sadece yetenekli çalışanları ile değil aynı zamanda tüm iş gücü ile varlıklarını sürdürürler.

Örgütlerde yetenek yönetimi, çekme, yerleştirme, geliştirme ve elde tutma olarak dört boyutta (Philips ve Edwards, 2009) veya belirleme, geliştirme ve kültür (Davies ve Davies, 2014) olmak üzere üç boyutta incelenmektedir. Bu üç boyut aynı zamanda Ooi'un (2009) yetenek yönetimi aşamaları olarak belirlediği bul-geliştir-tut adımlarına benzemektedir. Yeteneğin belirlenmesi, örgütün kendi çalışanları arasında ya da dış kaynaklardan yetenekli olanların bulunması ile gerçekleşir. Yetenekli bireylerin örgüt içindeki, hali hazırda var olan insan kaynaklarından sağlanması için ilk adım 
performans değerlendirmedir (Davies ve Davies, 2014; Ooi, 2009). Bu sayede çalışanlar tam olarak tanınacak ve gelişme için potansiyel belirlenebilecektir. Yetenekli bireylerin dış kaynaklardan belirlenmesi aşamasında ise üniversite öğrenimlerine devam edenler, mezunlar ve diğer örgütlerde çalışanlara yönelik bir cazibe kaynağı olmayı sağlayacak eylemler gereklidir. Ayrıca bir diğer önemli nokta da belirlenen yeteneğin örgüte kazandırılması, yani işe almadır.

Yeteneğin belirlenip işe alımından sonra öğrenme ve gelişim başlar. Bu süreçte yeteneğin belirginleşmesi ve yeni ortama uyumun sağlanması için geleneksele bağı kalmadan bir geliştirme programı hazırlamak gerekmektedir (Philips ve Edwads, 2009). Burada önemli olan noktalardan biri çalışanların tamamı için mi yoksa belirli bir yüzde için mi yetenek geliştirme etkinliklerinin sağlanacağıdır (Davies ve Davies, 2014). Bu stratejik bir karar olmakla birlikte örgütün kaynakları ve fırsat eşitliği de sınırlayıcı etkenlerden biridir.

Yetenek yönetiminin bir diğer boyutu ise yetenek kültürüdür. Güçlü bir yetenek yönetimi kültürüne sahip örgütlerde yeteneğe ilişkin değerler örgüt üyelerinin çoğunluğu tarafından benimsenir ve paylaşılır. Örgütlerde yetenek kültürü ne kadar benimsenir ve çalışanlar ne kadar bu kültürle bütünleşirse yetenek yönetimi uygulamalarının başarısız olma olasılığı o kadar azalacaktır. Yetenek yönetimini örgütün bir parçası haline getirmek de önemlidir. Yetenek yönetimi kültürünü oluşturmak en önemli görev yöneticilere düşmektedir ve bir yenilik başlatma olarak değerlendirilebilecek olan yetenek kültürü oluşturmak liderlik becerilerini de gerekli kılmaktadır. Davies ve Davies'in (2014) de belirttiği gibi bu aşamada liderlere düşen görevler, yeteneklere engel olmadan onu geliştirici ve birleştirici olmak ve güven oluşturmaktır.

Yetenek yönetiminin başarılı olabilmesi için yetenekli çalışanların kazandırılmasında en az üst yönetim kadar orta düzey yöneticilerinin de önemli görevleri bulunmaktadır (Altınöz, 2009). Yetenek yönetiminde orta seviye yöneticiler köprü görevi görmektedir. Nitekim yetenek yönetimi örgütlerin her düzeyinde yaşatılırsa başarılı olmaktadır. Orta seviyede ki yöneticiler, tepe yönetim ve insan kaynakları kısmıyla eşgüdümlü çalışarak yetenek yönetimini çalışanların kabul etmesi süre zarfında, yönetimi temsil eder. Nitekim potansiyel yetenekleri ilk fark edebilecek olan insanlar yine orta düzey yöneticilerdir (Atlı, 2012).

Yetenekli bireylerin sadece örgüte dahil edilmesi yeterli değildir. Bu yetenekli bireylerin arzulanan en üst düzeyde katkılarının sağlanabilmesi için yetenek yönetimi süreçlerinin, ilke ve uygulamaların etkin bir şekilde hayata geçirilmesi gerekmektedir (Tabancalı ve Korumaz, 2014). Okulların amaçlarını gerçekleştirmeleri ve etkililikleri onların insan kaynaklarından yararlanabilme düzeyine bağlıdır. Örgütlerde her çalışan önemlidir ancak söz konusu okullar olduğunda en önemli insan kaynağının öğretmenler olduğu rahatlıkla söylenebilir. Okulları daha ileriye götürecek, yenilenmesine ve değişmesine katkı sağlayacak öğretmenlerle çalışmak önemli bir yönetim stratejisi olarak karşımıza çıkmaktadır.

Türkiye'de ilk olarak işletmelerde çalışılan yetenek yönetimi ile ilgili son yıllarda eğitim kurumlarında da çalışmaların arttığı görülmektedir (Tabancalı ve Korumaz, 2014; Aytaç, 2014, Demirkasımoğlu ve Taşkın, 2015; Tabancalı, Şimşek ve Korumaz, 2015, Akar ve Balcı, 2016). Çünkü rekabet sadece işletmelerde değil eğitim örgütlerinde de daha yetenekli işgörenlerle çalışmayı gerekli kılmaktadır. Buna rağmen yetenek yönetimi özellikle eğitim alanında hala yeni bir çalışma alanıdır denebilir. Özellikle kamu eğitim kurumlarında uygulanması ile ilgili hala kapsamlı çalışmalara gereksinim vardır.

\subsection{Araştırmanın Amacı}

Bu araştırmanın amacı, özel okullarda yetenek yönetimi uygulamalarının gerçekleşme düzeyini belirlemektir.

Bu amaçla aşağıdaki alt problemlere yanıt aranmıştır:

1. Özel okullarda yetenek yönetimi uygulamalarının düzeyi nedir?

2. Özel okullarda yetenek yönetimi uygulamalarının düzeyi öğretmenlerin yaşına, cinsiyetine, kıdemine, branşına ve öğrenim düzeyine göre anlamlı bir şekilde farklılaşmakta mıdır? 


\section{YÖNTEM}

\subsection{Araştırma Modeli}

Bu araştırma tarama türünde desenlenmiş betimsel bir araştırmadır.

\subsection{Evren ve Örneklem}

Araştırmanın çalışma evrenini i̇stanbul illi Avrupa yakasında bulunan özel ilkokul, ortaokul ve ortaöğretim okulları oluşturmaktadır. Avrupa yakasında toplam 124 özel okul bulunmaktadır. Okul öncesi eğitim kurumları araştırmaya dahil edilmemiştir. Araştırmanın örneklemini basit tesadüfi yöntemle belirlenmiş olan 257 öğretmen oluşturmuştur. Araştırmaya katılan öğretmenlerin demografik özelliklerine dair bilgiler aşağıda verilmiştir.

Tablo 1. Örnekleme alınan öğretmenlerin demografik bilgileri

\begin{tabular}{|c|c|c|c|c|c|c|c|}
\hline & & $f$ & $\%$ & & & $f$ & $\%$ \\
\hline \multirow{2}{*}{ Cinsiyet } & Kadın & 164 & 63.8 & \multirow{3}{*}{$\begin{array}{l}\text { Çalıştığı } \\
\text { Kurum }\end{array}$} & İlkokul & 82 & 31.9 \\
\hline & Erkek & 93 & 36.2 & & Ortaokul & 90 & 35.0 \\
\hline \multirow{4}{*}{ Yaş } & 30 ve alt & 130 & 50.6 & & Lise & 85 & 33.1 \\
\hline & $31-40$ & 101 & 39.3 & \multirow{5}{*}{$\begin{array}{l}\text { Kıdem Süresi } \\
(Y, I)\end{array}$} & $1-5$ & 113 & 44.0 \\
\hline & 41 ve üzeri & 26 & 10.1 & & $6-10$ & 68 & 26.5 \\
\hline & & & & & $11-15$ & 52 & 20.2 \\
\hline \multirow{2}{*}{$\begin{array}{l}\text { Öğrenim } \\
\text { Durumu }\end{array}$} & Lisans & 219 & 85.2 & & $\begin{array}{c}16 \text { yll ve } \\
\text { üzeri }\end{array}$ & 24 & 9.3 \\
\hline & Lisansüstü & 38 & 14.8 & & & & \\
\hline
\end{tabular}

Tablo 1'e göre öğretmenlerin \%31.9'u ilkokul, \%35'i ortaokul ve \%33.1'i liselerde görev yapmaktadırlar. Katılımcıların \% 63.8'i kadın ve \%36.2'si erkektir. Katılımcıların yarısının 30 yaş ve altında olduğu ve \%44'ünün 1-5 yıllık kıdeme sahip olduğu görülmektedir. Katılımcılara ilişkin diğer demografik bilgiler tablo 1'de verilmiştir.

\subsection{Veri Toplama Aracı}

Araştırmada veriler Özel Okullar iç̧in Yetenek Yönetimi Ölçeği aracılığı ile toplanmıştır. Yetenek yönetimi ile ilgili alan yazın tarandığında; işletmelerde yetenek yönetimi uygulamalarının düzeyini belirlemek için Tutar, Altınöz ve Çöp (2011) tarafından Yetenek Yönetimi Ölçeği geliştirilmiştir. Eğitim örgütlerinde yetenek yönetimi uygulamalarını ölçmek amacıyla Tabancalı, Şimşek ve Korumaz (2015) tarafından Eğitim Örgütlerinde Yetenek Yönetimi Ölçeği geliştirilmiştir. Ayrıca Akar ve Balcı (2016) tarafından da Üniversite Yetenek Yönetimi Ölçeği geliştirildiği görülmektedir. Ancak özel okullar için geliştirilmiş bir ölçeğin olmaması nedeniyle araştırmacılar tarafından Türkiye koşullarında ve özel okullarda kullanılabilecek olan Özel Okullar İçin Yetenek Yönetimi Ölçeği (ÖOiYYÖ) geliştirilmiştir. Ölçek 5'li Likert tipinde hazırlanmıştır. Ölçeğin geçerlik ve güvenirlik analizleri ile ilgili bilgiler aşağıda verilmiştir.

\subsubsection{Geçerlik Analizleri}

Ölçek geliştirme sürecinde madde havuzunu oluşturabilmek için öncelikle konu ile ilgili alanyazın ayrıntılı biçimde taranmıştır. Örgütlerde yetenek yönetimini temel alarak geliştirilmiş ölçekler (Tutar, Altınöz ve Çöp, 2011, Demirkasımoğlu ve Taştan, 2015; Tabancalı, Şimşek ve Korumaz, 2015; Akar ve Balcı, 2016) ve yapılmış araştırmalar ayrıntılı olarak incelenmiştir. Bu araştırma sürecinin ardından toplam 30 maddelik (item) bir havuz oluşturulmuştur. Her bir madde ile ilgili alan uzmanı 3 akademisyenin görüşlerine başvurulmuştur. Uzman görüşleri arasındaki uyum/uyumsuzluk aynı zamanda kapsam ya da yapı geçerliği için birer gösterge olarak kullanılmaktadır. Ayrıca uzmanların sorunlu olduğunu ifade ettikleri maddelerin öneriler doğrultusunda düzeltmeleri yapılımışır. Bu işlemlerin ardından 5 maddede öneriler doğrultusunda düzeltilmiş, 1 madde çıkarılmıştır. Böylelikle taslak ölçek 29 maddeden oluşmuştur. Genel uygulamaya geçilmeden önce 50 öğretmene pilot uygulama yapılmış, maddeler üzerinde fark edilmemiş bir hata olup olmadığı incelenmiştir. Bu 
hazırlıkların ardından ölçeğin nasıl uygulanacağına dair ayrıntılı bir yönerge oluşturularak genel uygulamaya geçilmiştir.

\subsubsection{Yapı Geçerliği}

Faktör analizi, bir konuda katılımcıların verdiği cevaplara göre değişkenler arasındaki korelasyonun hesaplanarak, birbiri ile ilişkili olan ve aynı boyutu ölçen değişkenlerin gruplandırılması sonucu faktör elde etme işlemidir (Ural ve Kılıç, 2005). Özel okullar için yetenek yönetimi ölçeğinin (ÖOiYYÖ) faktör yapısını ortaya çıkarmak amacıyla sırasıyla açımlayıcı ve doğrulayıcı faktör analizi yapıımıştır.

Açımlayııı Faktör Analizi (AFA): ÖOiYYÖ’nün faktör yapısını belirlemek amacıyla açımlayııı faktör analizi yapılmıştır. Verilerin faktör analizi yapmaya uygun olup olmadığını belirlemek amacıyla örneklem uygunluğu (sampling adequacy) ve Barlett Sphericity testleri yapılmıştır. Verilerin faktör analizine uygunluğu için Kaiser-Meyer-Olkin bulunan değerin 1'e yaklaştıkça kabul edilebilir ve iyi düzeyde, 0.50'nin altında ise kabul edilemeyeceğini göstermektedir. Diğer yandan faktör analizinde evrendeki dağılımın normal olması gerekir. Verilerin çok değişkenli normal dağılımdan gelip gelmediği Bartlett's testi ile test edilmektedir (Otrar, Gulten ve Ozkan, 2012). KMO örneklem uygunluk katsayısı .96 ve Barlett Sphericity Testi $\chi 2$ değeri ise $5128.719(p<.00)$ olarak bulunmuştur. Bu sonuçlar verilerin faktör analizi için uygun ve yeterli olduğunu, Bartlett's değerlerinin anlamlılı̆ı da verilerin çok değişkenli normal dağılımdan geldiklerini göstermektedir.

Faktör yük değeri maddelerin alt boyutlarla olan ilişkisini açıklayan bir katsayıdır. Alanyazında faktör örüntüsünün oluşturulmasında 0.30 ile 0.40 arasında değişen faktör yüklerinin en düşük nokta olarak alınabileceği belirtilmektedir (Büyüköztürk, 2002:127). Bu araştırmada alt kesme noktası olarak 0.53 kabul edilmiştir. Faktör analizinin ilk sonuçları incelendiğinde, bazı maddelerin faktör yük değerinin her iki faktörde de yüksek yük değerine sahip oldukları gözlenmiştir. 5. madde, 11. madde, 13. madde ve 24. maddeler bu nedenle ölçekten çıkarılmıştır. Bu işlemlerin ardından maddelerin faktörlere dağılımını belirlemek için Varimax dik döndürme analizleri gerçekleştirilmiş ve sonuçlar Tablo 2'te gösterilmiştir. Analizlerde öncelikle Eigen değeri 3 olarak belirlenmiş ve yapılan analizlerde 3 faktör olduğu belirlenmiştir. Buna göre toplam varyansın \%66.26'sını açıklayan üç boyutlu bir yapı elde edilmiştir. Ölçeğe ilişskin faktör yüklerinin .52 ile .86 arasında değiştiği görülmüştür (Tablo 2).

Tablo 2. Özel Okullar İçin Yetenek Yönetimi Ölçeği'nin Faktör Yükleri ve Madde-Toplam Korelasyonları

\begin{tabular}{|c|c|c|c|c|}
\hline Maddeler & $\begin{array}{l}\text { Madde-toplam } \\
\text { Korelasyonları }\end{array}$ & F1 & F2 & F3 \\
\hline $\begin{array}{l}\text { 4. Okulumuzda öğretmenlerin performanslarını } \\
\text { tam olarak sergileyebilecekleri demokratik bir } \\
\text { çalışma ortamı vardır. }\end{array}$ & .74 & .56 & & \\
\hline $\begin{array}{l}\text { 15. Okul yöneticilerimiz öğretmenlere yaratıcı olma } \\
\text { özgürlügü sunarlar. }\end{array}$ & .80 & .70 & & \\
\hline $\begin{array}{l}\text { 16. Okulumuzda öğretmenlerin kararlara } \\
\text { katılmaları sağlanır. }\end{array}$ & .76 & .82 & & \\
\hline 17. Okulumuzda tüm çalışanlara değer verilir. & .78 & .74 & & \\
\hline 18. Okulumuzda öğretmenlere yetki verilir. & .75 & .73 & & \\
\hline $\begin{array}{l}\text { 19. Okulumuzda öğretmenlerin bazı şeyleri farklı } \\
\text { yapmalarına olanak verilir. }\end{array}$ & .75 & .78 & & \\
\hline $\begin{array}{l}\text { 20. Okulumuzda öğretmenlerin farklı fikirler ortaya } \\
\text { atmaları desteklenir. }\end{array}$ & .78 & .82 & & \\
\hline $\begin{array}{l}\text { 21. Okulumuzda öğretmenlerden gelen öneriler } \\
\text { dikkate alınır. }\end{array}$ & .79 & .81 & & \\
\hline $\begin{array}{l}\text { 22. Okul yöneticilerimizin yenilikçi fikirleri olan } \\
\text { kişilerdir. }\end{array}$ & .82 & .67 & & \\
\hline
\end{tabular}




\begin{tabular}{|c|c|c|c|c|}
\hline Maddeler & $\begin{array}{l}\text { Madde-toplam } \\
\text { Korelasyonları }\end{array}$ & F1 & F2 & F3 \\
\hline $\begin{array}{l}\text { 23. Okul yöneticilerimiz fırsatları yakalama } \\
\text { konusunda uzmandırlar. }\end{array}$ & .72 & .59 & & \\
\hline $\begin{array}{l}\text { 25. Okul yöneticilerimiz gelecekteki eğilimlerin } \\
\text { etkisi konusunda bilinçli karar alabilirler. }\end{array}$ & .82 & .62 & & \\
\hline $\begin{array}{l}\text { 27. Okulumuzda öğretmen performansının } \\
\text { değerlendirileceği objektif kriterler vardır. }\end{array}$ & .74 & .66 & & \\
\hline 28. Okulumuzda öğretmenlerin başarıları kutlanır. & .71 & .58 & & \\
\hline $\begin{array}{l}\text { 29. Okulumuzda öğretmenlerin uzun vadeli bir } \\
\text { gelişim planları vardır. }\end{array}$ & .75 & .59 & & \\
\hline $\begin{array}{l}\text { 6. Okul yöneticileri okulun gelişimi için eğitimler } \\
\text { düzenlerler. }\end{array}$ & .60 & & .73 & \\
\hline $\begin{array}{l}\text { 7. Okulumuzda açık bir şekilde belirlenmiş } \\
\text { vizyonumuz vardır. }\end{array}$ & .66 & & .74 & \\
\hline $\begin{array}{l}\text { 8. Okulumuzda açık bir şekilde belirlenmiş } \\
\text { değerlerimiz vardır. }\end{array}$ & 69 & & .83 & \\
\hline $\begin{array}{l}\text { 9. Okul yöneticilerimiz yeni bilgileri araştıran } \\
\text { (öğrenmeye açık) kişilerdir. }\end{array}$ & .77 & & .64 & \\
\hline $\begin{array}{l}\text { 10. Okul yöneticileri öğretmenlerin öğrenen } \\
\text { bireyler olmaları için onları güdülerler. }\end{array}$ & .74 & & .67 & \\
\hline $\begin{array}{l}\text { 12. Okulumuzda işe alımda en yetkin kişinin } \\
\text { seçilmesine önem verilmektedir. }\end{array}$ & .70 & & .53 & \\
\hline $\begin{array}{l}\text { 14. Okul yöneticilerimiz çalışanları eğitim olanakları } \\
\text { ile ilgili bilgilendirirler. }\end{array}$ & .77 & & .65 & \\
\hline $\begin{array}{l}\text { 26. Okul yöneticilerimiz okulumuzda başarı kültürü } \\
\text { oluşturma konusunda çaba harcarlar. }\end{array}$ & .77 & & .58 & \\
\hline $\begin{array}{l}\text { 1.Okul yöneticileri yetenekli öğretmenlerin okuldan } \\
\text { ayrılmamaları için özen gösterirler. }\end{array}$ & .57 & & & .53 \\
\hline $\begin{array}{l}\text { 2. Okul yöneticileri çevre okullardaki yetenekli } \\
\text { öğretmenlerin okulumuzda çalışmaları için onları } \\
\text { davet ederler. }\end{array}$ & .45 & & & .86 \\
\hline $\begin{array}{l}\text { 3. Okul yöneticileri öğretmenlerin kendilerine özgü } \\
\text { yeteneklerini belirlemeye çalışırlar. }\end{array}$ & .67 & & & .52 \\
\hline Açıklanan varyans (\%) & & 33.37 & 22.83 & 10.05 \\
\hline Öz değer & & 8.34 & 5.70 & 2.51 \\
\hline
\end{tabular}

Faktör analizi sonucunda farklı faktörlerden yük veren maddeler (Madde 5, 11, 13, 24) ölçekten çıkarılmıştır. Bu maddeler ölçekten çıkarıldıktan sonra ölçekte birden fazla faktöre yüksek değer veren bir madde bulunmamaktadır. Ölçeğin alt boyutlarına giren maddeler ve madde sayıları Tablo 2'te sunulmuştur.

Tablo 3. Faktör Analizi Sonucunda Belirlenen Alt Boyutlar ve Bu Boyutlardan Yük Alan Maddeler

\begin{tabular}{lcc}
\hline Faktör & Madde Sayısı & Madde Numarası \\
\hline Yetenek Belirleme & 3 & $1,2,3$ \\
Yetenek Gelisstirme & 8 & $6,7,8,9,10,12,14,26$ \\
Yetenek Kültürü & 14 & $4,15,16,17,18,19,20,21,22,23,25,27,28,29$ \\
\hline
\end{tabular}

Tablo 3'de görüldüğü üzere belirlenen birinci faktör üç maddeden (1, 2, 3. maddeler); ikinci faktör sekiz maddeden $(6,7,8,9,10,12,14,26$. maddeler) ve üçüncü faktör de 14 maddeden $(4,15,16$, $17,18,19,20,21,22,23,25,27,28,29$. maddeler) oluşmaktadır. Ölçekte ters puanlanması gereken madde bulunmamaktadır. Son hâlinde ölçek 25 maddeden oluşmaktadır. Her bir faktör, ilgili faktörde yer alan maddeler incelenerek isimlendirilmiştir. Bu bağlamda birinci alt boyutun "Yetenek Belirleme" ikinci alt boyutu "Yetenek Geliştirme" ve üçüncü alt boyutu da "Yetenek Kültürü" olarak 
isimlendirilmesi uygun görülmüştür. Tüm faktörlerde ve toplamda puanların artması ilgili özelliğin artması şeklinde değerlendirilmektedir.

Tablo 4: Doğrulayıcı Faktör Analizi Sonucu Elde Edilen Uyum İndeksleri ve Yorumları

\begin{tabular}{|c|c|c|c|}
\hline $\begin{array}{l}\text { Uyum } \\
\text { Ölçüsü }\end{array}$ & Uyum Kriterleri & Elde Edilen Değer & Uyum \\
\hline$x^{2 / d f}$ & $\leq 3$ iyi uyum, $\leq 4-5$ Kabul Edilebilir Uyum & $(596.72 / 245) 2.43$ & Kabul \\
\hline RMSEA & $\begin{array}{c}\leq 0.05 \text { iyi uyum, } 0.06-0.08 \text { Kabul Edilebilir } \\
\text { Uyum }\end{array}$ & 0.075 & Kabul \\
\hline SRMR & $\begin{array}{c}\leq 0.05 \text { iyi uyum, } 0.06-0.08 \text { Kabul Edilebilir } \\
\text { Uyum }\end{array}$ & 0.047 & Kabul \\
\hline $\mathrm{NFI}$ & $\begin{array}{c}0.95 \text { iyi uyum, } \\
\text { 0.94-0.90 Kabul Edilebilir } \\
\text { Uyum }\end{array}$ & 0.97 & Kabul \\
\hline NNFI & & 0.98 & Kabul \\
\hline $\mathrm{CFI}$ & & 0.98 & Kabul \\
\hline $\mathrm{IFI}$ & & 0.98 & Kabul \\
\hline RFI & & 0.97 & Kabul \\
\hline
\end{tabular}

x2/df = Ki-kare serbestlik derecesi oranı, RMSEA: Yaklaşık Hataların Ortalama Karekökü, NFI: Normlaştııımış uyum indeksi, CFI:Uyum Indeksi, IFI:Artan Uyum İndeksi, RFI:Göreli Uyum Indeksi

Uyum Indeksi (CFI), Artan Uyum İndeksi (IFI), Göreli Uyum İndeksi (RFI), Normlaştırılmış Uyum Indeksi(NFI), Normlaştırılmamış Uyum İndeksi (NNFI) için değerlerin 0.95 'ten büyük olması iyi uyum, 0.90-0.94 arası değerler ise kabul edilebilir uyum düzeyi olarak belirtilmektedir. Yaklaşık Hataların Ortalama Karekökü (RMSEA) ve Standart ortalama karekök hatası (SRMR) değerlerinin 0.05 'ten küçük olması iyi uyum, 0.06-0.08 arasında olması ise kabul edilebilir uyum olarak belirtilmektedir (Hair, Anderson, Tatham ve Black, 1998). Bu ölçütler doğrultusunda ölçeğin üç faktörlü yapısının DFA verilerine göre doğrulandığı söylenebilir (Tablo 4).

\subsubsection{Güvenirlik Analizleri}

ÖOiYYÖ'nin güvenirliği iç tutarlılık ve test-tekrar test yöntemleri ile hesaplanmıştır. Ölçeğin iç tutarlıık katsayısı (Cronbach's Alpha) her bir alt boyut için; yetenek kültürü alt boyutunda .96, yetenek geliştirme alt boyutunda .92 , yetenek belirleme alt boyutunda .68 ve özel okullar için yetenek yönetimi ölçeğinin toplamında ise .96 olarak bulunmuştur. Test tekrar test güvenirliğini sınamak amacıyla ölçek iki hafta ara ile 56 öğretmene uygulanmıştır. İki uygulama arasındaki korelasyon katsayısı ise .82 olarak bulunmuştur. Tavşancıl'a (2002) göre bir ölçeğin zamana göre değişmez olduğunu saptamak üzere hesaplanan korelasyon katsayısının pozitif ve yüksek olmasının yanında ölçekler için bu değerin en az 0.70 olması istenir. Bu verilere göre ölçeğin güvenirlik katsayılarının yeterli olduğu söylenebilir.

\subsection{Verilerin Analizi}

Araştırma verileri; cinsiyet, yaş ve çalıştığı kurum değişkenleri için her bir alt boyutta Skewness ve Kurtosis değerleri $-1.5<x<+1.5$ aralığında olduğundan (Tabachnick and Fidell, 2013) ve levene analizine göre varyansların homojen olduğu görülmüştür. Normal dağılım gösterdiği varsayılmıştır. Cinsiyet ve yaş değişkenlerinin analizinde t-testi ve One-Way ANOVA testleri kullanılmıştır. Araştırma verileri; öğrenim durumu ve kıdem değişkenleri için her bir alt boyutta Skewness ve Kurtosis değerleri $-1.5<x<+1.5$ aralığında (Tabachnick and Fidell, 2013) ancak levene analizine göre varyansların homojen olmadığı görülmüştür. Normal dağılım göstermediği varsayılmıştır. Öğrenim durumu ve kıdem değişkenlerinin analizinde Kruskal-Wallis testi ve Mann-Whitney $U$ testi kullanılmıştır. Veriler, sosyal bilimler için geliştirilmiş olan istatistik programı (SPSS) yardımıyla analiz edilmiştir. Sonuçlar $p<.01$ ve $p<.05$ düzeyinde test edilmiştir. Beşli Likert tipinde hazırlanan ölçeklerden elde edilen puanlar, (1.00-1.80) “Hiç". (1.81-2.60) "düşük", (2.61- 3.40) "Orta", (3.41-4.20) 
"yüksek" ve (4.21-5.00) ise "çok yüksek" şeklinde değerlendirilmiştir. Korelasyon katsayısının mutlak değer olarak; 0.00 - 0.29 "düşük". 0.30 - 0.69 "orta" ve 1.00 - 0.70 ise "yüksek" düzeyde ilişki olarak yorumlanmıştır. Korelasyon katsayısının mutlak değer olarak; 0.00 - 0.29 "düşük", 0.30 - 0.69 "orta" ve 0.70 - 1.00 ise "yüksek" düzeyde ilişki olarak yorumlanmıştır (Büyüköztürk, 2009).

\section{BULGULAR}

Aşağıda öğretmenlerin yetenek yönetimi uygulamalarına ilişkin görüşlerinin betimsel istatistikleri ve demografik değişkenlere ilişkin bulgulara yer verilmiştir

Tablo 5. Öğretmenlerin Yetenek Yönetimi Uygulamalarına İlişkin Görüşlerinin Betimsel İstatistikler

\begin{tabular}{lccc}
\hline & $\mathrm{N}$ & $\overline{\boldsymbol{X}}$ & $\mathrm{SS}$ \\
\hline Yetenek Belirleme & 257 & 3.24 & 0.91 \\
Yetenek Geliştirme & 257 & 3.60 & 0.86 \\
Yetenek Kültürü & 257 & 3.30 & 0.92 \\
Yetenek Yönetimi Toplam & 257 & 3.39 & 0.84 \\
\hline
\end{tabular}

Araştırmaya katılan öğretmenlerin yetenek yönetimi uygulamalarına ilişkin görüşleri Tablo 2'de verilmiştir. Tabloya göre öğretmenlerin yetenek belirleme $\bar{X}=3.24$, yetenek kültürü $\bar{X}=3.30$ boyutlarına ilişkin ve yetenek yönetiminin toplamına $\bar{X}=3.39$ ilişkin görüşleri "orta" düzeyde bulunmuştur. Yetenek geliştirme boyutunda $\bar{X}=3.60$ ise öğretmenlerin görüşlerinin "yüksek" düzeyde bulunmuştur. Her bir alt boyutta en yüksek ve en düşük puanlar incelendiğinde, yetenek belirleme boyutunda "Okul yöneticileri yetenekli öğretmenlerin okuldan ayrılmamaları için özen gösterirler." maddesi, yetenek geliştirme boyutunda "Okulumuzda açık bir şekilde belirlenmiş değerlerimiz vardır." maddesi ve yetenek kültürü boyutunda ise "Okul yöneticilerimiz gelecekteki eğilimlerin etkisi konusunda bilinçli karar alabilirler." maddesinin en yüksek ortalamaya sahip oldukları bulunmuştur

Tablo 6. Cinsiyet Değişkenine Göre Yetenek Yönetimi Uygulamalarına Yönelik Öğretmen Görüşlerine Iliş̧kin T - Testi Sonuçları

\begin{tabular}{|c|c|c|c|c|c|c|c|}
\hline Boyutlar & Cinsiyet & $\mathrm{N}$ & $\overline{\mathbf{X}}$ & SS & sd & $\mathrm{t}$ & $p$ \\
\hline \multirow[t]{2}{*}{ Yetenek Belirleme } & Kadın & 164 & 3.21 & 0.92 & \multirow{2}{*}{255} & \multirow{2}{*}{-.628} & \multirow{2}{*}{.53} \\
\hline & Erkek & 93 & 3.29 & 0.88 & & & \\
\hline \multirow{2}{*}{ Yetenek Geliştirme } & Kadın & 164 & 3.58 & 0.89 & \multirow{2}{*}{255} & \multirow{2}{*}{-.385} & \multirow{2}{*}{.70} \\
\hline & Erkek & 93 & 3.63 & 0.81 & & & \\
\hline \multirow{2}{*}{ Yetenek Kültürü } & Kadın & 164 & 3.27 & 0.93 & \multirow{2}{*}{255} & \multirow{2}{*}{-.688} & \multirow{2}{*}{.49} \\
\hline & Erkek & 93 & 3.35 & 0.91 & & & \\
\hline \multirow{2}{*}{$\begin{array}{l}\text { Yetenek Yönetimi } \\
\text { Toplam }\end{array}$} & Kadın & 164 & 3.36 & 0.86 & \multirow{2}{*}{255} & \multirow{2}{*}{-.630} & \multirow{2}{*}{.52} \\
\hline & Erkek & 93 & 3.43 & 0.82 & & & \\
\hline
\end{tabular}

Tablo 6'da görüldüğü gibi yetenek yönetimi uygulamalarına yönelik; yetenek belirleme $\left[\mathrm{t}_{(255)}=-.628\right.$ $p>0.05]$, yetenek geliştirme $\left[t_{(255)}=-.385 ; p>0.05\right]$ ve yetenek kültürü $\left[t_{(255)}=-.688 ; p>0.05\right]$ boyutuna ve yetenek yönetimi toplamına $\left[\mathrm{t}_{(255)}=-.630 ; \mathrm{p}>0.05\right]$ ilişkin öğretmenlerin görüşleri cinsiyet değişkenine göre istatistiksel olarak anlamlı bir fark göstermemektedir. Bu bulgu cinsiyet değişkeninin yetenek yönetimi ve tüm alt boyutlarında anlamlı bir belirleyici olmadığını göstermektedir. Erkek öğretmenlerin tüm alt boyutlara ve yetenek yönetimi toplamına ilişkin görüşleri kadın öğretmenlere göre daha yüksektir. Ancak bu fark istatistiksel olarak anlamlı değildir. 
Tablo 7. Yaş Değişkenine Göre Yetenek Yönetimi Uygulamalarına Yönelik Öğretmen Görüşlerine Illişkin Varyans Analizi Sonuçları

\begin{tabular}{llllllll}
\hline Boyutlar & Yaş & $\mathrm{N}$ & $\overline{\mathbf{X}}$ & $\mathrm{SS}$ & sd & $\mathrm{F}$ & $\mathrm{P}$ \\
\hline \multirow{2}{*}{ Yetenek Belirleme } & $20-30$ yıl & 130 & 3.29 & 0.91 & 2 & & \\
& $31-40$ yıl & 101 & 3.21 & 0.91 & 254 & .49 & .61 \\
& 41 yıl ve üzeri & 26 & 3.12 & 0.89 & 256 & & \\
\hline \multirow{2}{*}{ Yetenek Geliştirme } & $20-30$ yıl & 130 & 3.68 & 0.80 & 2 & & \\
& 31-40 yıl & 101 & 3.57 & 0.81 & 254 & 2.39 & .09 \\
& 41 yıl ve üzeri & 26 & 3.29 & 0.84 & 256 & & \\
\hline \multirow{3}{*}{ Yetenek Kültürü } & $20-30$ yıl & 130 & 3.34 & 0.91 & 2 & & \\
& 31-40 yıl & 101 & 3.30 & 0.92 & 254 & .95 & .38 \\
\hline \multirow{2}{*}{ Yetenek Yönetimi } & 41 yıl ve üzeri & 26 & 3.07 & 1.02 & 256 & & \\
Toplam & $20-30$ yıl & 130 & 3.45 & 0.80 & 2 & & \\
& 31-40 yıl & 101 & 3.37 & 0.86 & 254 & 1.40 & .24 \\
\hline
\end{tabular}

Tablo 7 incelendiğinde yetenek yönetimi uygulamalarına yönelik; yetenek belirleme $\left[F_{(2-256)}=.49\right.$; $p>0.05]$, yetenek geliştirme $\left[F_{(2-256)}=2.39 ; p>0.05\right]$ ve yetenek kültürü $\left[F_{(2-256)}=.95 ; p>0.05\right]$ boyutuna ve yetenek yönetimi toplamına $\left[\mathrm{F}_{(2-256)}=1.40 ; p>0.05\right]$ ilişkin öğretmenlerin görüşleri arasında yaş değişkeni bakımından anlamlı bir fark olmadığı görülmektedir. Bu bulgu yaş değişkeninin yetenek yönetimi ve tüm alt boyutlarında anlamlı bir belirleyici olmadığını göstermektedir.

Tablo 8. Çalıştığı Kurum Değişkenine Göre Yetenek Yönetimi Uygulamalarına Yönelik Öğretmen Görüşlerine iliş̧kin Varyans Analizi Sonuçları

\begin{tabular}{llllllll}
\hline Boyutlar & Çalıştığı Kurum & $\mathrm{N}$ & $\overline{\mathbf{X}}$ & $\mathrm{SS}$ & sd & $\mathrm{F}$ & $\mathrm{p}$ (Tukey b) \\
\hline \multirow{2}{*}{ Yetenek Belirleme } & ilkokul (1) & 82 & 3.36 & 0.84 & 2 & & \\
& Ortaokul (2) & 90 & 3.23 & 0.90 & 254 & 1.20 & .30 \\
& Lise (3) & 85 & 3.14 & 0.97 & 256 & & \\
\hline \multirow{2}{*}{ Yetenek Geliştirme } & illkokul (1) & 82 & 3.82 & 0.78 & 2 & & \\
& Ortaokul (2) & 90 & 3.53 & 0.92 & 254 & 4.12 & .01 * 1-2,3 \\
& Lise (3) & 85 & 3.45 & 0.85 & 256 & & \\
\multirow{2}{*}{ Yetenek Kültürü } & ilkokul (1) & 82 & 3.45 & 0.92 & 2 & & \\
& Ortaokul (2) & 90 & 3.29 & 0.94 & 254 & 2.11 & .12 \\
& Lise (3) & 85 & 3.16 & 0.90 & 256 & & \\
\multirow{2}{*}{ Yetenek Yönetimi } & ilkokul (1) & 82 & 3.56 & 0.78 & 2 & & \\
Toplam & Ortaokul (2) & 90 & 3.36 & 0.88 & 254 & 2.85 & .06 \\
& Lise (3) & 85 & 3.25 & 0.84 & 256 & &
\end{tabular}

Tablo 8 incelendiğinde yetenek yönetimi uygulamalarına yönelik; yetenek belirleme $\left[F_{(2-256)}=1.20\right.$; $p>0.05]$ ve yetenek kültürü $\left[F_{(2-256)}=2.11 ; p>0.05\right]$ boyutuna ve yetenek yönetimi toplamına $\left[F_{(2-256)}=\right.$ 2.85; p>0.05] ilişkin öğretmenlerin görüşleri arasında çalıştığı kurum değişkeni bakımından anlamlı bir fark olmadığı görülmektedir. Yetenek geliştirme boyutunda ise öğretmenlerin görüşleri arasında kıdem değişkeni bakımından anlamlı bir fark bulunmuştur $\left[F_{(2-256)}=4.12 ; p<0.05\right]$. Bu bulgu çalıştığı kurum değişkeninin sadece yetenek geliştirme alt boyutunda anlamlı bir belirleyici olduğunu göstermektedir. Yapılan Tukey-b testi sonuçlarına göre ilkokullarda görev yapan öğretmenlerin görüşlerinin, ortaokul ve liselerde görev yapan öğretmenlerin görüşlerinden farklılaştığı bulunmuştur. 
Tablo 9. Öğrenim Durumu Değişkenine Göre Yetenek Yönetimi Uygulamalarına Yönelik Öğretmen Görüşlerine Iliş̧kin Mann-Whitney U Testi Sonuçları

\begin{tabular}{llccccc}
\hline Boyut & Grup & $\mathrm{N}$ & $\begin{array}{c}\text { Sıra } \\
\text { Ortalaması }\end{array}$ & Sıra Toplamı & U & $\mathrm{p}$ \\
\hline Yetenek Belirleme & Lisans & 219 & 131.76 & 28855.00 & 3557 & .150 \\
& Lisansüstü & 38 & 113.11 & 4298.00 & & \\
\hline Yetenek Geliştirme & Lisans & 219 & 130.08 & 28488.50 & 3923 & .574 \\
& Lisansüstü & 38 & 122.75 & 4664.05 & & \\
\hline Yetenek Kültürü & Lisans & 219 & 130.93 & 28673.50 & 3738 & .318 \\
& Lisansüstü & 38 & 117.88 & 4479.50 & & \\
\hline Yetenek Yönetimi & Lisans & 219 & 130.91 & 28669.00 & 3743 & .323 \\
Toplam & Lisansüstü & 38 & 118.00 & 4484.00 & & \\
\hline
\end{tabular}

Tablo 9'da görüldüğü gibi yetenek yönetimi uygulamalarına yönelik; yetenek belirleme $[(U=3557$, $p>0.05)]$, yetenek geliştirme $[(U=3923, p>0.05)]$, ve yetenek kültürü $[(U=3738, p>0.05)]$, boyutuna ve yetenek yönetimi toplamına $[(U=3743, p>0.05)]$, ilişkin öğretmenlerin görüşleri öğrenim durumu değişkenine göre istatistiksel olarak anlamlı bir fark göstermemektedir. Bu bulgu öğrenim durumu değişkeninin yetenek yönetimi ve tüm alt boyutlarında anlamlı bir belirleyici olmadığını göstermektedir. Lisans mezunu olan öğretmenlerin tüm alt boyutlara ve yetenek yönetimi toplamına ilişkin görüşleri lisansüstü mezunu olan öğretmenlere göre daha yüksektir. Ancak bu fark istatistiksel olarak anlamlı değildir.

Tablo 10. Kıdem Değişkenine Göre Yetenek Yönetimi Uygulamalarına Yönelik Öğretmen Görüşlerine Illişkin Kruskal-Wallis Testi Sonuçları

\begin{tabular}{|c|c|c|c|c|c|c|c|}
\hline Boyut & Gruplar & $\mathrm{N}$ & $\begin{array}{c}\text { Sıra } \\
\text { Ortalaması }\end{array}$ & $\mathrm{sd}$ & $x^{2}$ & $p$ & $\begin{array}{c}\text { Anlamlı } \\
\text { Fark }\end{array}$ \\
\hline Yetenek & $1-5(A)$ & 113 & 130.80 & 3 & 5.42 & .143 & \\
\hline \multirow[t]{3}{*}{ Belirleme } & $6-10(B)$ & 68 & 125.86 & & & & \\
\hline & $11-15(C)$ & 52 & 115.97 & & & & \\
\hline & 16 yıl ve üzeri(D) & 24 & 157.67 & & & & \\
\hline Yetenek & $1-5(A)$ & 113 & 140.21 & 3 & 7.97 & .043 & $A-B$ \\
\hline \multirow[t]{3}{*}{ Geliştirme } & $6-10(B)$ & 68 & 108.79 & & & & \\
\hline & $11-15(C)$ & 52 & 127.10 & & & & \\
\hline & 16 yıl ve üzeri(D) & 24 & 137.60 & & & & \\
\hline Yetenek & $1-5(A)$ & 113 & 128.60 & 3 & 2.97 & .395 & \\
\hline \multirow[t]{4}{*}{ Kültürü } & $6-10(B)$ & 68 & 124.13 & & & & \\
\hline & $11-15(C)$ & 52 & 125.09 & & & & \\
\hline & 16 yıl ve üzeri(D) & 24 & 153.17 & & & & \\
\hline & $1-5(A)$ & 113 & 131.02 & 3 & 3.53 & .314 & \\
\hline Yetenek & $6-10(B)$ & 68 & 119.75 & & & & \\
\hline Yönetimi & $11-15(C)$ & 52 & 126.01 & & & & \\
\hline Toplam & 16 yıl ve üzeri(D) & 24 & 152.17 & & & & \\
\hline
\end{tabular}

Tablo 10 incelendiğinde yetenek yönetimi uygulamalarına yönelik; yetenek belirleme $\left[X^{2}{ }_{(3)}=5.42\right.$; $p>0.05]$, yetenek kültürü $\left[X^{2}{ }_{(3)}=2.97 ; p>0.05\right]$ boyutuna ve yetenek yönetimi toplamına $\left[X^{2}{ }_{(3)}=3.53\right.$; $p>0.05$ ] ilişkin öğretmenlerin görüşleri arasında kıdem değişkeni bakımından anlamlı bir fark olmadığı görülmektedir. Bu bulgu kıdem değişkeninin; yetenek belirleme ve yetenek kültürü alt boyutları ile yetenek yönetimi toplamına anlamlı bir belirleyici olmadığını göstermektedir. Yetenek geliştirme $\left[X^{2}{ }_{(3)}=7.97=2.46 ; p>0.05\right]$ alt boyutunda ise öğretmenlerin görüşleri arasında kıdem değişkeni bakımından anlamlı bir fark bulunmuştur. Mann-Whitney $U$ testi ile yapılan çoklu karşılaştırmalar sonucunda bu farkın 1-5 yıl kıdeme sahip olanlarla 6-10 yıl kıdeme sahip olanlar arasında olduğu belirlenmiştir. 


\section{SONUÇ VE TARTIŞMA}

Özel okullarda yetenek yönetimi uygulamalarının gerçekleşme düzeyini belirlemek amacıyla yapılan araştırmada öğretmenlerin yetenek belirleme, yetenek kültürü boyutlarına ilişkin ve yetenek yönetiminin toplamına ilişkin görüşleri "orta" düzeyde, yetenek geliştirme boyutunda ise öğretmenlerin görüşleri "yüksek" düzeyde bulunmuştur. Yükseköğretim kurumlarında yapılan araştırmalardan; Akar ve Balcı (2016) tarafından yapılan bir araştırmaya göre, üniversitelerde yetenek yönetimi uygulanma düzeyi toplamda ve alt boyutlarda "düşük" düzeyde bulunmuştur. Bu bulgular ile araştırma bulguları farklılık göstermektedir. Bunun nedeni öğretim kademelerinin farklı olması şeklinde açıklanabilir. Diğer taraftan ortaöğretim kurumlarında, Aytaç (2015) tarafından yapılan bir araştırmada öğretmen algılarına göre okul yöneticilerinin yetenek yönetimi liderliği düzeyleri orta olarak bulunmuş aynı zamanda Demirkasımoğlu ve Taştan (2015) özel öğretim kurumlarında yetenek yönetimi uygulamalarının "orta" düzeyde olduğunu belirlemişlerdir. Bu bulgular ile araştırma bulguları oldukça benzerlik göstermektedir. Diğer araştırmalardan farklı olarak yetenek geliştirme boyutunda uygulamaların "yüksek" düzeyde bulunması; örnekleme alınan özel okullardaki yetenek yönetimi uygulamalarının diğer araştırmalara dahil edilen okullardan daha yüksek olarak algılanması şeklinde açıklanabilir.

Araştırmada öğretmen görüşlerine göre; yetenek yönetimi uygulamalarında ilk sırada yetenek geliştirme, ikinci sırada yetenek kültürü ve üçüncü sırada ise yetenek belirleme alt boyutlarındaki uygulamaların olduğu bulunmuştur. Özel okullardaki yetenek belirleme uygulamalarının en düşük olarak değerlendirildiği göze çarpmaktadır. Bunun nedeninin Türkiye'de özel okulların sayısının artması ayrıca dershanelerin kapatılarak temel liselere dönüştürülmesi sürecinin etkili olduğu söylenebilir. Ancak araştırma bulgusundan farklı olarak diğer araştırmalarda (Akar ve Balcı, 2016; Rudhumbu, 2014) işe çekme boyutunun en yüksek puan aldığı bulunurken, Demirkasımoğlu ve Taştan (2015) işe çekme boyutunun daha düşük puan aldığını bulunmuştur.

Yetenek yönetimi uygulamalarına yönelik; yetenek belirleme, yetenek geliştirme ve yetenek kültürü boyutlarına ve yetenek yönetimi toplamına ilişkin öğretmenlerin görüşleri cinsiyet, öğrenim durumu ve yaş değişkenlerine göre istatistiksel olarak anlamlı bir farklılık göstermemektedir. Bu bulgu Demirkasımoğlu ve Taştan (2015)'ın çalışması ile örtüşmektedir.

Çalıştığı kurum ve kıdem değişkenlerine göre ise yetenek geliştirme boyutunda istatistiksel olarak anlamlı bir fark vardır. Illkokullarda görev yapan öğretmenlerin görüşlerinin, ortaokul ve liselerde görev yapan öğretmenlerin görüşlerinden farklılaştığı bulunmuştur. Bununla birlikte kıdem değişkenine göre bu farkın 1-5 yıl kıdeme sahip olanlarla 6-10 yıl kıdeme sahip olanlar arasında olduğu belirlenmiştir.

Bulgular ışı̆̆ında; yetenek kültürü ve yetenek belirleme noktalarında özel okullardaki uygulamaların artırılabilmesi için özel okullardaki yöneticilere yetenek yönetimi konusunda eğitimler verilebilir. Sonraki araştırmalarda farklı ve daha kapsamlı örneklemler üzerinden veriler toplanarak, bulgular karşılaştırılabilir. Farklı değişkenlerin yetenek yönetimi uygulamalarının yordayıcısı-ilişkisi olup olmadığı ortaya konabilir. Bununla birlikte daha ayrıntılı veri toplamak için nitel araştırma yöntemleri kullanılarak araştırmalar yapılabilir

\section{Kaynakça}

Akar, F. ve Balcı, A. (2016). Yetenek Yönetiminin Bazı Türk Üniversitelerinde Uygulanmasına Illişkin Öğretim Üyesi Görüşleri. Kastamonu Ĕ̆itim Dergisi, 24(2), 955-974.

Altuntuğ, N. (2009). Rekabet Üstünlüğünün Sürdürülmesinde Yeteneklerin Rolü: Yetenek Yönetimi Yaklaşımı. Süleyman Demirel Üniversitesi iktisadi ve Idari Bilimler Fakültesi Dergisi, 14(3), 453460.

Atlı, D. (2012). Yetenek Yönetimi. İstanbul: Crea Yayıncılık 
Axelrod, E. L., Handfield-Jones, H. ve Welsh, T. A. (2001). The War for Talent, Survey-Part Two. McKinsey Quarterly, 2, 9-12.

Aytaç, T. (2014). Okullarda Bütünleştirilmiş Yetenek Yönetimi Modeli: Öğretmen Görüşleri. Eğitim Bilimleri Dergisi, 39: 1-24

Aytaç, T. (2015). The Relationship Between Teachers' Perception about School Managers' Talent Management Leadership and the Level of Organizational Commitment. Eurasian Journal of Educational Research, 59, 165-179.

Blass, E. (2009). Systems and Structures to Support Talent Management. In Talent Management (pp. 154-162). Palgrave Macmillan UK.

Born, M. ve Heers, M. (2009). Talent Management: Alternatives to the Single-Ladder Approach. Faculty Report (pp. 1-108). Copenhagen, Denmark: DEA - Danish Business Research Academy.

Demirkasımoğlu, N. ve Taşkın, P. (2015). Yetenek Yönetiminin Örgütsel Etkililik ile iliş̧kisi: Özel Öğretim Kurumları Örneği. Eğitim ve Öğretim Araştırmaları Dergisi, 4(4), 268-285.

Ertürk, M. (2011). Insan Kaynakları Yönetimi. İstanbul: Beta Yayınevi.

Hay, M. (2002). Strategies for Survival in the War of Talent. Career Development International, 7(1), 52-55.

Gülfidan, İ. ( 2008). Yetenek Yönetimi: Harvard Business Review Dergisinden Seçmeler: İstanbul: Mess Yayınları.

Lewis, R. E. ve Heckman, R. J.(2006). Talent Management: A Critical Review. Human Resource Management Review, 16, 139-15.

McKinsey ve Company, Inc. (2001, April). The War for Talent, Organization and Leadership Practice, USA.

Ooi, C. S. S. (2009). Surviving the War for Talent in Asia: How Innovation Can Help, Portable Documents. Pearson Education.

Otrar, M., Gülten, D. Ç. ve Özkan, E. (2012). Ilköğretim Öğrencilerine Yönelik Öğrenme Stilleri Ölçeği Geliştirilmesi (Aös-i ). Eğitim ve Öğretim Araştırmaları Dergisi Journal of Research in Education and Teaching. 1(2),ISNN: 2146-9199.

Philips, J. J. ve Edwards, L. (2009). Managing Talent Retention: An ROI Approach. Pfeiffer Publishing: San Francisco.

Rudhumbu N. (2014). Implementation of Talent Management Strategies in Higher Education: Evidence from Botswana, International Journal of Higher Education Management (IJHEM), 1(1), 86-99.

Tabancalı, E. ve Korumaz, M. (2014). Eğitim Örgütlerinde Yetenek Yönetimi. The Journal of Academic Social Science Studies, 25(1), 139-156.

Tabancalı, E., Şimşek, G. G. ve Korumaz, M. (2015). Eğitim Örgütlerinde Yetenek Yönetimi Ölçeği Geliştirme Çalışması. 2nd International Eurasian Educaiıonal Research Congress. Ankara.

Tavsancıl, E. (2002). Tutumların Ölçülmesi ve SPSS'le Veri Analizi. Ankara: Nobel Yayınları.

Tutar, H., Altınöz, M. ve Çöp, S. (2011). İşletmelerde Yetenekli Çalışanların Örgütsel Bağlılıklarının Artırılmasına Yönelik Bir Araştırma. 19. Ulusal Yönetim ve Organizasyon Kongresi, 306-312. Çanakkale.

Ural, A. ve Kılıç, I. (2005). Bilimsel Araştırma Süreci ve SPSS ile Veri Analizi. Ankara: Detay Yayıncılık. 


\section{Extended Summary}

The purpose of this study is to determine actualization levels of talent management implementations on private schools. In order to reach the aim of this study, the following research questions have been addressed:

1.What is the level of teachers' opinions about levels of talent management implementations in private schools

2.Does actualization levels of talent management implementations in private schools differ according to the variables of sex, age, Seniority, branch and Educational background?

The study is designed in the survey model. Target population of the study is primary, elementary and high private schools in European side of Istanbul. The sample of the study consists of 257 teachers. The sample was chosen through simple random sampling.

Information regarding the demographic features of teachers in the sampling are provided in Table 1. Accordingly, $31.9 \%$ of the teachers (82) are working at primary schools, $\% 35$ (90) at elementary schools and \%33.1 (85) at high schools. $63.8 \%$ (264) of the participants are female and $36.2 \%(93)$ are male. Other demographic information of participants is provided in Table

The data of the study was collected through "Talent Management Scale for Private Schools (TMSFPS)" that include three sub-dimensions and 25 items. This scale was developed by researchers for private schools in Turkey. In order to analyze the data, standard deviation, mean, independent samples t-test, one-way ANOVA analysis were used.

The scale was a measuring tool of 5-point grading type including 25 items and three sub fields. CFA results $(\mathrm{x} 2 / \mathrm{df}=2.43, \mathrm{RMSEA}=.07, \mathrm{SRMR}=.04, \mathrm{NFI}=.97, \mathrm{NNFI}=.98, \mathrm{RFI}=.97, \mathrm{IFI}=.98$, and $\mathrm{CFI}=.98$ ) indicated that the scale had an acceptable goodness of fit. It was determined that Cronbach's alpha internal consistency reliability was high, item total correlations were high.

Exploratory factor analysis (EFA) and confirmatory factor analysis (CFA) methods were used in order to determine the construct validity TMSFPS. First of all Kaiser-Meyer-Olkin (KMO) testing sample adequacy was examined in order to be made exploratory factor analysis through the data obtained from 257 teachers. KMO value was found to be 0.96. According to Kaiser (1974), KMO values above 0.5 are acceptable values. It is stated that KMO value must be higher than 0.60 , and Spehericity and Barlett test must be meaningful for factor analysis (Büyüköztürk, 2007). Secondly, Bartlett's Spehericity test was analyzed $(\chi 2=5128.719, p<.000)$ and it was determined that the obtained data were suitable for factor analysis. In the first factor analysis, 4 items in the 29 itemtrial form were removed from the scale because their factor loadings were below 0.30 , they take place in multiple factors and the differences between the factors were less than 0.10 . It was seen that item-total correlations were received values between 0.45 and 0.82 . Calculated for the reliability of the scale, Cronbach's alpha was found to be. 96 . For the scale stability, test-retest reliability coefficient was found to be .82 . The findings show that the scale has adequate validity and reliability to measure talent management.

According to the findings obtained from this study, the level of teachers' opinions regarding talent determining dimension, talent culture dimension and talent management was determined to be moderate. However, their levels of talent developing dimension were found to be high. In addition, it identified that the opinions of teachers' regarding the talent management implementations showed statistical no significant differences according to gender, age and educational level variables. The opinions of teachers' regarding the talent management implementations showed statistical significant differences according to the organization where s/he works variable. Opinions of primary school teachers' differ from opinions of elementary school teachers' and high school teachers'. According to seniority variable in talent development dimension, this difference was found to be between those who have 1-5 years of seniority and those who have 6-10 years of seniority. 